\title{
The Eagle and the Phoenix
}

\author{
Clay B. Marsh, MD'
}

ABSTRACT

Author affiliations are

listed at the end of this

West Virginia and rural America have deep roots of community, hospitality, and selfreliance. We have the courage to go under the ground to mine the coal and to make steel with vats of boiling liquid. We are artisans, and we know how to live with the land. These skills were lost in time, deemed unnecessary by affluence. But the COVID-19 pandemic changed that.

article.

Correspondence to:

Clay B. Marsh, MD

West Virginia University

Health Sciences

cbmarsh@hsc.wvu.edu

\section{KEYWORDS}

COVID-19, Rural Communities

Rural America has not fared well in the new economy. An economy of hedge funds, investment bankers, venture capitalists, and the ultra-rich controls most of the wealth in our country. It is an economy that has pivoted from the manufacturing of goods and services to one that favors the trading of currency existing in the mind of a computer network.

In America, we have traded self-sufficiency for the pursuit of wealth and power. We buy things from other countries rather than manufacture them ourselves. We used to produce the components and materials to make the things that ran the world. We used to make things better than anyone in the world.

Areas of America that led our economy during the Industrial Revolution were left behind with the rise of this new economy. Many of these places are in rural America and in West Virginia and have consequently grown older and poorer. We did not build large cities and large airports to attract people. So the people went to the coasts, the oceans, and the big cities.

More and more, it became winner-take-all. The rich got richer and the poor got poorer.
In rural America, we experienced an identity crisis. We forgot our proud heritage and our strength. We suffered deaths of hopelessness and despair. We turned to drugs to hide our pain and to escape.

But West Virginia and rural America have deep roots of community, hospitality, and self-reliance. We have the courage to go under the ground to mine the coal and to make steel with vats of boiling liquid. We are artisans, and we know how to live with the land.

These skills were lost in time, deemed unnecessary by affluence. But the COVID-19 pandemic changed that.

This pandemic changed everything. Suddenly, large cities and metropolitan areas were vulnerable. With so many people living together, the virus spread quickly from person to person. The surge of sickness started to overwhelm healthcare workers and hospitals. The economy that was built on trading things like currency and futures displayed its fragility.

We were the country that bought the goods produced by other countries, but our supply chains broke. They broke under the stress of the COVID-19 virus in China, where our vital personal protective 
equipment (PPE) is made. They broke in Italy, where our swabs to perform COVID-19 testing are made. And they broke in Europe, where the COVID-19 tests are designed. We had to start to rebuild our supply chain while under the immense stress of this new pandemic.

We had to quickly learn how to respond to COVID-19. We joined together with our neighbors, and we started to make things again. We began to answer the call of self-reliance.

In West Virginia, our people banded together in spirit by separating physically to protect themselves, their families, and their communities. We pushed to protect our front-line workers. We starved the virus from its rapid spread by reducing person-to-person contact. We started making masks, gowns, face shields, and other protective equipment. We started making the swabs for the tests, and then, the tests themselves.

We started to pull from the foundation of our country. We are the eagle soaring again. In the face of great adversity, we find the best in ourselves, in our neighbors, and in West Virginia.

We are the phoenix rising from the ashes in this time of transformational change. A recent study found that West Virginia has handled this crisis better than any state to date. ${ }^{1}$

We have struggled and suffered much in rural America and in Appalachia, but we are smart, resourceful, and strong. We are mountaineers.

And, although we will all be challenged in the aftermath of the COVID-19 pandemic, we will rely on our heritage to push ahead. It is our time to rise, to be resilient, and to serve each other. Our strength is based on our ability to sustain ourselves and our families and to pull our act together during times of great challenge.

We are strong in America. We are strong in rural America. We always have been. Together. E Pluribus Unum. Out of Many, One.

\section{AUTHOR AFFILIATION}

1. West Virginia University Health Sciences, Morgantown, West Virginia

\section{REFERENCES}

1. Laycock R. Government reaction times to COVID-19. Finder. Available from https://www. finder.com/government-reaction-times-tocovid-19. April 23, 2020. Accessed April 24, 2020. 